\title{
Samvalgsveiledning kan gi pasienter bedre helsekunnskap
}

Når helsepersonell gir samvalgsveiledning og

kunnskapsbasert informasjon, får muligens pasientene $\varnothing \mathrm{kt}$ kunnskap om behandlingens fordeler og ulemper.

\section{Simone Kienlin}

Sykepleier, ph.d.-stipendiat og spesialrådgiver

Universitetssykehuset Nord-Norge, UiT - Norges arktiske universitet og Samvalg Helse

Sør-Øst

\section{Therese Kristine Dalsbø}

Seniorrådgiver

Cochrane Norge

Samvalgsverktøy

Samvalgsveiledning

Kunnskapsbasert informasjon

Helsevalg

Sykepleien Forskning 202217 (88047) (e-88047)

DOI: 10.4220/Sykepleienf.2022.88047

Det er fortsatt behov for mer forskning på effekter av samvalgsveiledning når helsevalg skal tas. Det viser en systematisk oversikt fra Cochrane.

\section{Hva sier forskningen?}

I systematiske oversikter samles og vurderes tilgjengelig forskning. Denne Cochrane-oversikten unders $\emptyset$ kte hva som skjer når helsepersonell tilbyr samvalgsveiledning til personer som står overfor en helsebeslutning, sammenliknet med vanlig omsorg eller kun informasjon. 
Oversikten så på effektene av hvor godt pasienten hadde fått forberedt seg til helsebeslutningen, kunnskap om pasientens preferanser, trygghet $\mathrm{i} a ̊$ ta beslutning sammen med helsepersonell, kunnskap om behandlingens forventede positive og negative effekter og pasientens følelse av å være godt informert.

Det var fire sammenlikninger, hvorav tre kun hadde resultater med svært liten tillit.

Forskningen om samvalgsveiledning og kunnskapsbasert informasjon sammenliknet med vanlig praksis viser at samvalg

- muligens gir pasienter økt kunnskap.

Vi vet ikke med sikkerhet effekten på andre utfall om beslutningstaking, angst og depresjon fordi vi har svært liten tillit til resultatene.

Tabell 1. Sammenlikning av vanlig praksis mot samvalgsveiledning og kunnskapsbasert informasjon

\begin{tabular}{|c|c|c|c|}
\hline Hva skjer? & Vanlig praksis & Samvalg & $\begin{array}{l}\text { Tillit til } \\
\text { resultatet }^{1}\end{array}$ \\
\hline $\begin{array}{l}\text { Kunnskap } \\
\text { Pasienter som får samvalgsveiledning sammen } \\
\text { med kunnskapsbasert informasjon, făr muligens } \\
\text { økt kunnskap sammenliknet med de som făr vanlig } \\
\text { praksis }\end{array}$ & $\begin{array}{l}\text { Gjennomsnittlig fra 27, } 51 \\
\text { til 54,7 } \\
\text { poeng på en skala fra 0-100, der } \\
\text { høyere skåring betyr mer kunnskap }\end{array}$ & $\begin{array}{l}9,33 \text { h } \varnothing \text { yere } \\
\text { poeng på skala fra 0- } \\
100 \text { (fra 6,55 til 12,1 } \\
\text { høyere)* }\end{array}$ & $\begin{array}{l}\oplus \oplus \bigcirc \bigcirc \\
\text { Liten }\end{array}$ \\
\hline $\begin{array}{l}\text { Opplever pasientene å være } \\
\text { - } \quad \text { godt forberedt til å ta en beslutning } \\
\text { - } \quad \text { trygge på å ta en beslutning } \\
\text { - } \quad \text { godt informert } \\
\text { - } \quad \text { kjent med sine egne verdier og } \\
\text { preferanser } \\
\text { - } \quad \text { støttet i beslutningsprosessen } \\
\text { - } \quad \text { angrende overfor behandlingsvalget } \\
\text { - } \quad \text { engstelige eller deprimerte }\end{array}$ & \multicolumn{2}{|c|}{$\begin{array}{l}\text { Vi vet ikke effekten av samvalgsveiledning på disse utfallene } \\
\text { fordi vi har svært liten tillit til resultatet }\end{array}$} & $\begin{array}{l}\oplus \bigcirc \bigcirc \bigcirc \\
\text { Svært liten }\end{array}$ \\
\hline
\end{tabular}

\section{Bakgrunn}

Samvalg er en form for strukturert samarbeid der pasienten og helsepersonellet sammen kommer frem til hvilken behandling, diagnostikk og oppfølging som passer best. Samvalg er aktuelt i beslutninger som innebærer valg mellom flere tilgjengelige og forsvarlige behandlingsalternativer, der pasientenes egne prioriteringer er viktige.

Dette kan være aktuelt for eksempel i vurderinger av hvilken kirurgisk behandling man skal velge ved brystkreft, om man skal ta PSA-test ved prostataplager, eller hvilke legemidler man skal ta for eksempel mot depresjon eller diabetes.

\section{«Samvalgsveiledning benyttes for å veilede og støtte pasienter som står overfor et helsevalg.»}


Samvalgsveiledning benyttes for å veilede og støtte pasienter som står overfor et helsevalg. Veiledningen utføres av helsepersonell som sykepleiere, leger, farmas øyter, fysioterapeuter eller sosionomer. De får opplæring i å veilede og støtte pasienter som står overfor en beslutning, til å oppnå et informert samvalg.

Informasjonen handler både om mulige fordeler og ulemper samt å få frem pasientens preferanser. Samvalgsveiledning tar sikte på å støtte voksne og barn til å delta i valg rundt sin egen helse for å forbedre kvaliteten på beslutningsprosessen og følgelig kvaliteten på beslutningen.

En samvalgsveileder har ulike oppgaver fra å veilede pasienten i deler av beslutningsprosessen, som informasjonsformidling eller preferansekartlegging, til å gjennomføre en fullstendig samvalgsprosess. Hvilke oppgaver en samvalgsveileder får ansvaret for i en samvalgsprosess, er først og fremst et spørsmål om hva slags problemstilling beslutningen gjelder.

Det er utviklet flere opplæringsmoduler innen rammeverket som heter Klar for samvalg. Hensikten er å bidra til implementering av samvalg ved å styrke helsepersonellets kompetanse i å involvere pasienter i beslutninger om egen helse.

Én av modulene er et kurs for sykepleiere og annet helsepersonell som har i oppgave å støtte pasienter og pårørende i hele eller deler av samvalgsprosessen og i bruk av samvalgsverkt $\varnothing y$ der det er aktuelt.

Digitale samvalgsverktøy skal inneholde kunnskapsbasert informasjon og er et sentralt tiltak som er utviklet for å st øtte pasienten og helsepersonellet til å få felles kjennskap til pasientens preferanser.

Verktøyene skal hjelpe dem i å vurdere fordeler og ulemper med behandlingen ut fra hva som er viktigst for den konkrete pasienten, og dermed komme frem til hva som vil være best behandling. Det finnes nasjonale samvalgsverktøy på norsk hos helsenorge.no.

\section{Hva er denne informasjonen basert på?}

Forfatterne av Cochrane-oversikten gjorde et s $\varnothing \mathrm{k}$ i aktuelle forskningsdatabaser i juni 2021 og fant 28 randomiserte kontrollerte studier med til sammen 5509 personer.

Det er fire studier som avventer en beslutning på om de skal med eller ikke. I tillegg er det 16 pågående studier som kan inkluderes i en fremtidig oppdatering. Studiene hadde svært ofte uklar rapportering om det metodiske opplegget, særlig om blinding og selektiv rapportering, men også om randomiseringsprosedyre. 
Tabell 2. Inklusjonskriterier og inkluderte studier

\begin{tabular}{|c|c|c|}
\hline PICO & Hva lette de etter? & Hva fant de? \\
\hline Populasjon & $\begin{array}{l}\text { De så etter studier som inkluderte voksne og barn } \\
\text { som forbereder seg på å ta en beslutning om } \\
\text { behandling, screening eller diagnostikk for seg selv } \\
\text { eller et annet familiemedlem. De kan inkludere } \\
\text { alternativet ikke å gjøre noe. }\end{array}$ & $\begin{array}{l}\text { Studiene handlet om bruk av samvalgsveiledning for å } \\
\text { støtte beslutninger om behandling }(n=18) \text { eller screening } \\
(n=10) \text {. Helsebeslutninger handlet om kreft }(n=6) \text {, } \\
\text { overgangsalder }(n=2) \text {, psykiske lidelser }(n=2) \text {, avansert } \\
\text { nyresykdom }(n=1) \text {, lumbal stenose }(n=1) \text {, prevensjon ( } n \\
=1) \text {, menoragi }(n=1) \text {, diabetisk fotsår }(n=1) \text {, multippel } \\
\text { sklerose }(n=1) \text {, slitasjegikt }(n=1) \text { og embryooverføring ( } n \\
=1) \text {. Andre beslutninger handlet om kreftscreening }(n=4) \\
\text { og genetisk testing }(n=6) \text {. Gjennomsnittsalderen var } 48 \\
\text { år, og ingen studier handlet om barn. En overvekt av } 64 \\
\text { prosent var kvinner. }\end{array}$ \\
\hline $\begin{array}{l}\text { Tiltak og } \\
\text { sammenlikning }\end{array}$ & $\begin{array}{l}\text { Samvalgsveiledning som var definert som } \\
\text { ikke-instruerende støtte av helsepersonell. Alle } \\
\text { typer helsepersonell som er kurset i samvalg for å } \\
\text { forberede pasienten til å ta en beslutning var } \\
\text { relevant. Samvalgsveiledning som var gjennomført } \\
\text { ansikt til ansikt eller gjennom andre løsninger, ble } \\
\text { inkludert. Samvalgsveiledningen måtte være } \\
\text { sammenliknet med vanlig praksis eller andre tiltak. }\end{array}$ & $\begin{array}{l}\text { Samvalgsveiledning ble gitt av sykepleiere }(n=10) \text {, } \\
\text { genetiske rådgivere }(n=4) \text {, psykologer }(n=3) \text {, en } \\
\text { farmas } \varnothing y t(n=1) \text {, en blanding av helsepersonell }(n=2) \\
\text { eller andre med opplæring i beslutningsveiledning }(n=8) \text {. } \\
\text { De fleste studiene rapporterte at veiledningen skjedde } \\
\text { personlig }(n=16) \text { og/eller via telefon }(n=12) \text {. Tiden som } \\
\text { ble brukt, varierte fra åtte minutter til to timer, } \\
\text { gjennomsnittlig } 31 \text { minutter. }\end{array}$ \\
\hline Utfall & $\begin{array}{l}\text { Forfatterne så etter en rekke utfall som } \\
\text { pasientenes kunnskap om behandlingen, deres } \\
\text { livskvalitet, om de følte seg klare for samvalg, om } \\
\text { de fikk kjennskap til egne verdier og preferanser, } \\
\text { om pasientene opplevde medvirkning, og om de } \\
\text { var tilfredse med samvalgsprosessen. Det ble også } \\
\text { sett etter data om helsesystemets ressursbruk, } \\
\text { som tid og penger. }\end{array}$ & $\begin{array}{l}\text { De færreste studiene hadde målt eller rapportert alle } \\
\text { utfallene likt. Derfor er analysene svært begrenset. For } \\
\text { analysene som ligger i de fire resultattabellene, var det } \\
\text { mellom en og fem studier for hvert utfall. Vi har kun } \\
\text { rapportert om analysen med fem studier, som hadde } \\
1073 \text { deltakere. }\end{array}$ \\
\hline Setting & Studier ble inkludert uansett hvor de var utført. & $\begin{array}{l}\text { Studiene var utført i USA }(n=13) \text {, Canada }(n=4) \text {, Tyskland } \\
(n=4) \text {, England }(n=4) \text {, Australia, }(n=1) \text {, Japan }(n=1) \text { og } \\
\text { Nederland }(n=1) \text {. }\end{array}$ \\
\hline Tillit til resultatet & Tillit til resultatene ble vurdert i henhold til GRADE. & $\begin{array}{l}\text { Alle utfall var gradert til svært liten tillit. Det var kun ett } \\
\text { utfall de hadde liten tillit til. Hovedărsaken til at de trakk } \\
\text { ned tilliten, var selve gjennomføringen av studiene samt at } \\
\text { studiene ikke ga like nok resultater. }\end{array}$ \\
\hline
\end{tabular}

\section{Systematisk oversikt}

I systematiske oversikter søker man etter og oppsummerer studier som svarer på et konkret forskningsspørsmål. Studiene blir funnet, vurdert og oppsummert ved å bruke en systematisk og forhåndbeskrevet fremgangsmåte. (Les mer: Cochrane)

\section{Tillit til resultatet (GRADE)}

Når vi oppsummerer studier og presenterer et resultat, er det viktig å si noe om hvor mye tillit vi kan ha til dette. Det handler om hvor trygge vi kan være på at resultatet gjenspeiler virkeligheten. GRADE er et system vi bruker for å kunne bed $\varnothing \mathrm{mme}$ tilliten til resultatet. I GRADE vurderer vi blant annet

- hvor godt studiene er gjennomført

- om studiene er store nok

- om studiene er like nok

- hvor relevante studiene er 
- om alle relevante studier er fanget opp

\section{Kilde}

Jull J, Köpke S, Smith M, Carley M, Finderup J, Rahn AC, et al. Decision coaching for people making healthcare decisions. Cochrane Database of Systematic Reviews. 2021(11). DOI: 10.1002/14651858.CDo13385.pub2

Les hele Cochrane-oversikten her: Decision coaching for people making healthcare decisions 